\title{
Improving Yield and Performance of Shallot on Ultisol Through Application of Dolomite and Chicken Manure
}

\author{
Merakati Handajaningsih*, Hesti Pujiwati ${ }^{1}$, Doni Putra Pertama Nasution ${ }^{1}$, \\ Marwanto $^{1}$
}

\author{
${ }^{1}$ Department of Crop Production, Faculty of Agriculture, The University of Bengkulu \\ Jalan W.R. Supratman, Kandang Limun, Bengkulu, 38371.Indonesia. \\ *Corresponding author. Email:merakati@unib.ac.id
}

\begin{abstract}
Production area of some vegetables has been shifting from highland to lowland due to the decline of acreage. The main problems of growing shallot on ultisol Bengkulu are low soil $\mathrm{pH}$ and reduction of organic matter. The purpose of this study was to evaluate the shallot performance and yield after the application of dolomite and chicken manure. The study was conducted on the experimental field of the Faculty of Agriculture, University of Bengkulu from November 2018 to January 2019. Completely Randomized Design (CRD) was set in two factors and three replications. The factor of dosage of chicken manure consisted of four levels, they were 0 tons / ha, 10 tons / ha, 20 tons / ha, and 30 tons / ha. The other factor was the dosage of dolomite, based on exchangeable Aluminium (Al-ex), which consisted of four dosage levels e.i.: 0 Al-ex, 0.5 x Al-ex, 1 x Al-ex, and $1.5 \times$ Al-ex. Dosage of chicken manure and dolomite influenced tuber weight and tuber diameter. The dosage of $30 \mathrm{ton} / \mathrm{ha}$ of chicken manure and 1x Al-ex ( $3 \mathrm{ton} / \mathrm{ha}$ of dolomite) resulted in $7.40 \mathrm{~g}$ for tuber weight and $23.24 \mathrm{~mm}$ for tuber diameter. Addition of dolomite and chicken manure into Ultisol increased $\mathrm{pH}$ and lowered exchangeable Al. There is an indication that high dose application of chicken manure should be paired with lower dose of dolomite to enhance tuber growth of shallot. As single factor, both treatments had affected plant height, time to harvest, fresh weight, dry weight. The higher the dose of dolomite or chicken manure, the longer the days to harvest time.
\end{abstract}

Keywords: shallot, dolomite, chicken manure, ultisol, organic matter

\section{INTRODUCTION}

Shallot (Allium ascalonicum L.) is one of the most valuable vegetables in Indonesia. Its uses as spices in every Indonesian culinary is prominent. In addition, shallot is also commonly used as traditional medicine and ingredient of industrial food products. The importance of this comodity thus will be clear as the population of Indonesian increase. [1] Central Bureau of Statistics (2019) presented data of Indonesian population in 2019 was $268,074,600$ with the growth rate was $1.31 \%$. Consumption of shallot in Indonesia in $20182.496 \mathrm{~kg}$ per capita with the consumption growth rate is $2.53 \%$ [2] (General Secretary of Agriculture, 2019). This means that the demand for shallot will keep growing.

As the demand of shallot is increasing in the coming years, the production area is extended to areas other than the centers of shallot production such as in Bengkulu province. Shallot cultivation on lowland ultisol in Bengkulu, which is the main mineral soil type in Bengkulu, facing problems of low soil $\mathrm{pH}$ and low soil organic matter content. The most suitable soil $\mathrm{pH}$ for shallot is slightly acidic to neutral 5.5 - 7.0. Meanwhile, ultisol inthe reseacrh area in Bengkulu ha sa $\mathrm{pH}$ value of 4.9. The previous studies showed that liming can lower the soil acidity and increase the availability of phosphorus nutrient [3] [4] [5] Wahjudin, 2006). Moreover, liming 3 tons/ha on acid sulphate soil was proved to increase growth and yield of onion [4] while [5] revealed that liming was also beneficial in reducing exchangeable $\mathrm{Al}$ and lowering $\mathrm{Fe}$ and $\mathrm{Mn}$.

Chicken manure is wellknown to contain high levels of nitrogen and low level of water content. This condition thus stimulates microorganisms to make a rapid decomposition process. Chicken manure decomposes relatively quick so that nutrients are more available and is more quickly to be absorbed by plants. Applicating manure into the soil can improve soil structure and contribute soil nutrients [6]. Based on research conducted by [7] chicken compost contains macro elements of $\mathrm{N} 1.9 \%$, P $3.2 \%, \mathrm{~K} 2.7 \%$ and has as much organic C content 17, $62 \%$. The application of manure was able to provide the highest yields on the variable tuber diameter and fresh weight of shallot plants [8]. [9] further states that giving chicken manure has a significant effect on increasing plant length, number of tillers, fresh bulb weight per plot and tuber dry weight per plot. As well as to increase the growth 
and production of shallot plants, the best dose of chicken manure is given of 25 tons / ha.

The objective of this study was to evaluate growth and yield of shallot grown in ultisol Bengkulu amended with different dose of dolomite and chicken manure.

\section{MATERIALS AND METHODS}

\subsection{Time and place}

The research was conducted from November 2018 to January 2019 at the Experimental Field, Faculty of Agriculture, the University of Bengkulu, Bengkulu City. The planting material was shallot cultivar Bima Brebes taken from BALITSA (Indonesian Vegetables Research Institute), Lembang, West Java. Dolomite and local chicken manure were materials used for treatments.

\subsection{Research design}

The design used in this study was a completely randomized design (CRD) which was arranged in a factorial. The first factor is the application of chicken manure consisting of four levels of dosage, e.i. A1: $0 \mathrm{~g} /$ polybag, A2: 10 tons / ha $=44 \mathrm{~g} /$ polybag, A3: 20 tons $/$ ha $=88 \mathrm{~g} /$ polybag, A3: $30 \mathrm{ton} / \mathrm{h} \mathrm{a}=132 \mathrm{~g} /$ polyb $\mathrm{g}$. The second factor was dose of dolomite lime (D), which consists of four levels. They were D0: $0 \mathrm{x} \mathrm{Al}-\mathrm{ex}=0 \mathrm{~g} /$ polybag, D1: $0.5 \mathrm{x} \mathrm{Al}-\mathrm{ex}=7,36 \mathrm{~g} /$ polybag, D2: $1 \mathrm{x}$ $\mathrm{Al}-\mathrm{ex}=14.72 \mathrm{~g} /$ polybag, D3: $1.5 \mathrm{x} \mathrm{Al}-\mathrm{ex}=22.08 \mathrm{~g} /$ polybag. The exchangeable $\mathrm{Al}$ of the soil in $\mathrm{D} 2$ treatment is equal to 3.0 ton dolomite per hectare. Thus $1.5 \mathrm{x} \mathrm{Al-ex}$ was equal to dolomite 1.5 ton/ha, while $1.5 \mathrm{x} \mathrm{Al-ex} \mathrm{was}$ equal to dolomite 4.5 ton $/$ ha. Those 16 treatment combinations were repeated 3 times. Two polybags were set in each experimental unit.

\subsection{Pre-treatment soil and manure analysis}

Soil analysis was carried out in the Soil Science laboratory of the University of Bengkulu to determine the soil $\mathrm{pH}$, as well as the Al-ex of the soil. Analysis of chicken manure was carried out to determine the moisture content.

\subsection{Planting Procedures}

The media used in this study was Ultisol taken from undisrupted area in Experimental Field, Faculty of Agriculture, the University of Bengkulu. Chicken manure and dolomite were mixed into the soil according to the treatment, put into $40 \mathrm{~cm} \times 50 \mathrm{~cm}$ polybags. Chicken manure as well as dolomite were applicated 1 week before shallot planting. Each polybag was amended with fertilizers Urea $1.39 \mathrm{~g} /$ polybag, TSP $1.06 \mathrm{~g} /$ polybag, and $\mathrm{KCl} 0.73 \mathrm{~g} /$ polybag.

Plant maintenance was done according to standard procedure. Weeding was carried out manually every week both in the polybag area and the sorrounding planting area The plants were watered in the morning and late afternoon. Pest and disease were controlled preventively by spraying $80 \%$ mankozeb fungicide with a dose of $3 \mathrm{~g} / 1$ water and sprayed regularly once every 2 weeks on each plant inthe polybag.

Harvesting is carried out when the shallot plant has reached the harvest criteriaindicated by the base of the leaves are yellow and weakened, part of the tubers have appeared to the surface of the soil and the bulbs are purplish red, shallot bulb is dry and stiff. Harvesting was done by dismantling the plants from polybags.

\subsection{Data Collection and Analysis}

Data for plant growth and yield were collected according the following procedure. Plant height were measured at 6 weeks after planting. Number of leaves per cluster were counted at 6 weeks after planting. Time to harvest was measured from the time of planting to harvest. The number of tubers per cluster, tuber diameter was measured using a caliper by measuring the largest part of the shallot bulb. Tuber fresh weight was measured after cleaning the tubers from their leaves. Leaf dry weight was done by weighing the leaves that have been air-dried for 15 days.

The data obtained were analyzed statistically by Analysis of Variance (ANOVA) using the F test at the 5\% level. The trend of the treatment effect were analysed using Polynomial Orthogonal.

\section{RESULTS AND DISCUSSION}

The treatment of chicken manure and dolomite affected weight of bulb and bulb diameter. Combination of chicken manure 30 tones/ ha and dolomite 1x Al-ex yielded $7.40 \mathrm{~g}$ per shallot bulb (Figure 1). The lowest bulb weight was resulted from the plant which treated without dolomite, eventhough the chicken manure was pushed to high dose (30 tons/ha). Chicken manure and dolomite can improve the environmental conditions for shallots so that resulted in better growth. Dolomite is able to increase the $\mathrm{pH}$ of the soil and reduce Al-ex . This is inline with the result of the study [10] that showed interaction of compost application of 10 tons/ha and dolomite lime 1.4 tons / ha increased soil pH at 5.37. This study showed that application of dolomite at 1.5 ton/ha or 3 ton/ha less effected tuber weight when incorporated with low rate of chicken manure (10 ton/ha). Increasing dolomite to 3 ton/ha together with high dose of chicken manure (30 ton/ha) enhanced tuber weight. This indicated that more photosynthate was allocated to the tuber due to the improvement of soil condition. 


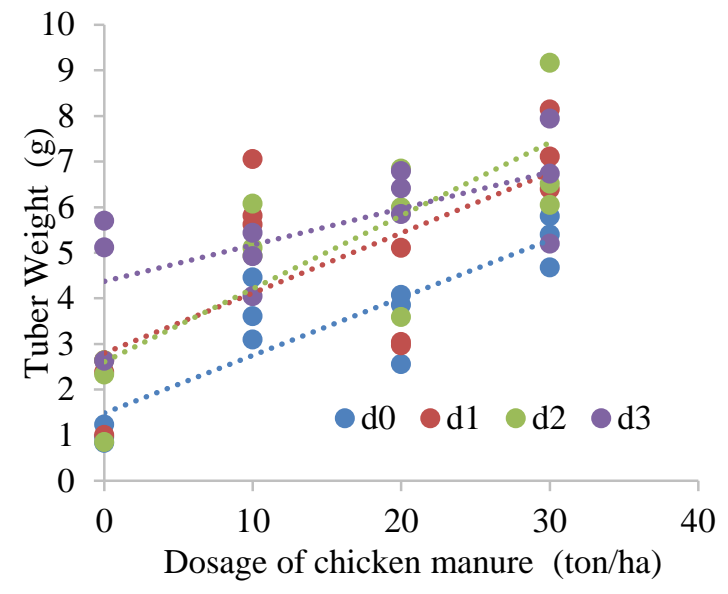

Figure 1. The relation of dose of chicken manure and tuber weight at different dose of dolomite

The increasing weight of shallot bulb from the treatment of dolomite $1 \mathrm{x} \mathrm{Al-ex}$ and chicken manure 30 tons/ha is due to the improvement of $\mathrm{pH}$ value from 4.9 to 5.8 at the end of the planting season (Table 1) compared to plants without additional dolomite nor chicken manure. These combination was also reduced Al-ex from 1,6 to 0,3. [11] Trakal et al. (2011) studied dolomite on the soil properties and they found that dolomite can increase the accumulation of plant biomass and reduce the uptake of some metals. The effect of treated the soil with dolomite and chicken manure on bulb diameter of shallot showed similarity to that of weight of bulb (Figure 2).

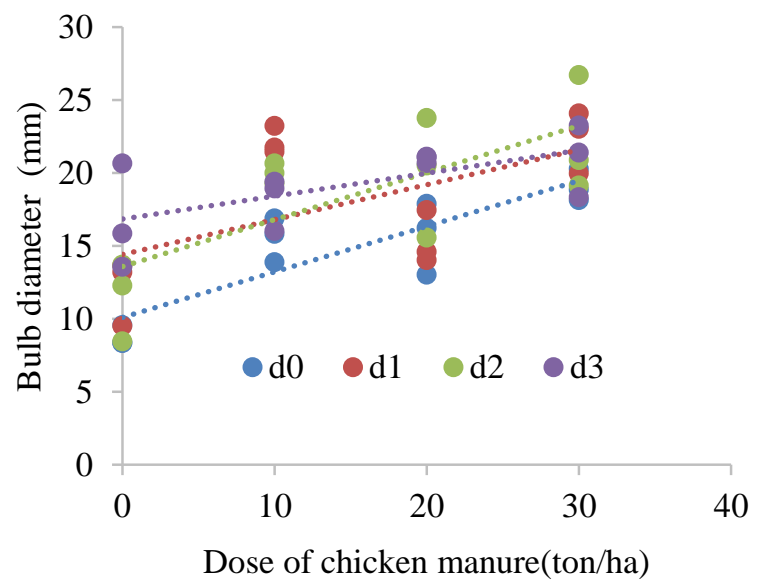

Figure 2. Effect of chicken manure on bulb diameter at different dose of dolomite

As single factor, application of dolomite or chicken manure to some extend promotes plant growth (plant height, shoot fresh weight, and shoot dry weight) and prolong time to harvest for 3 days compared to non treated plants (Figures
3, 4, and 5). Referring variety description, time to harvest for Bima Brebes is 65 days after planting. This work showed that shallot was harvested at 68 to 71,5 days after planting. Longer days to harvest time might be unintendedly, but it can be compensated by the higher yield.

Table 1. The changes values of $\mathrm{pH}$ and exchangeable $\mathrm{Al}$ before and after treatments.

\begin{tabular}{|l|c|c|c|}
\hline Parameter & Treatment & $\begin{array}{c}\text { Pre- } \\
\text { Treatment }\end{array}$ & $\begin{array}{c}\text { After- } \\
\text { Treatment }\end{array}$ \\
\hline $\mathrm{pH}$ & $0-0 \mathrm{x}$ Al-ex & 4.9 & 4.2 \\
\hline & $30-1,5 \times \mathrm{Al}-\mathrm{ex}$ & 4.9 & 5.8 \\
\hline $\mathrm{Al}-\mathrm{ex}(\mathrm{me} / 100 \mathrm{~g})$ & $0-0 \mathrm{x} \mathrm{Al-ex}$ & 1.6 & 1.3 \\
\hline & $10-0.5 \mathrm{x}$ Al-ex & 1.6 & 0,9 \\
\hline & $20-1 \times \mathrm{Al}-\mathrm{ex}$ & 1,6 & 0,2 \\
\hline & $30-1,5 \times \mathrm{Al}-\mathrm{ex}$ & 1,6 & 0,3 \\
\hline
\end{tabular}

Vegetative growth stage of plant is dominated by use of photosynthate mostly to doble cells and increase the cell size [12]. Net photosynthesis is reflected as plant dry weight. Shallot accumulate photosynthate in storage plant part called bulb. The high mass of dry weight and bulb weight are in line with the application dose of manure or dolomite. High photosyntatic rate and photosynthate accumulation are due to favor environment such as temperature, water absorption, and available esensial nutrients. Beside beneficial effecs of dolomite and manure in increasing nutrient and water uptake [13] [14], the presence of Nitrogen and Phosphor from inorganic fertilizers are also significance for the root environment [15] which resulted better dry weight.

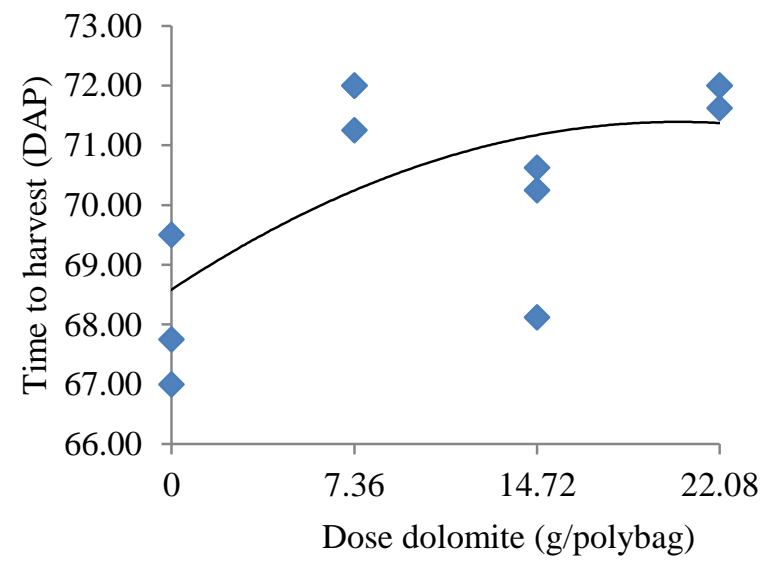

Figure 3. Effect of application of dolomite to time to harvest 


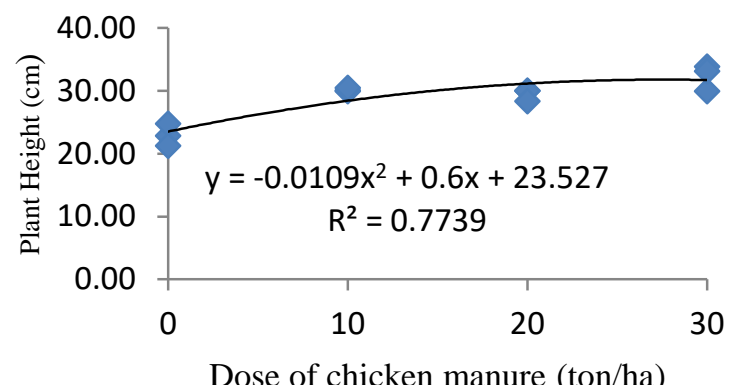

Figure 4. Effect of chicken manure on shallot plant height

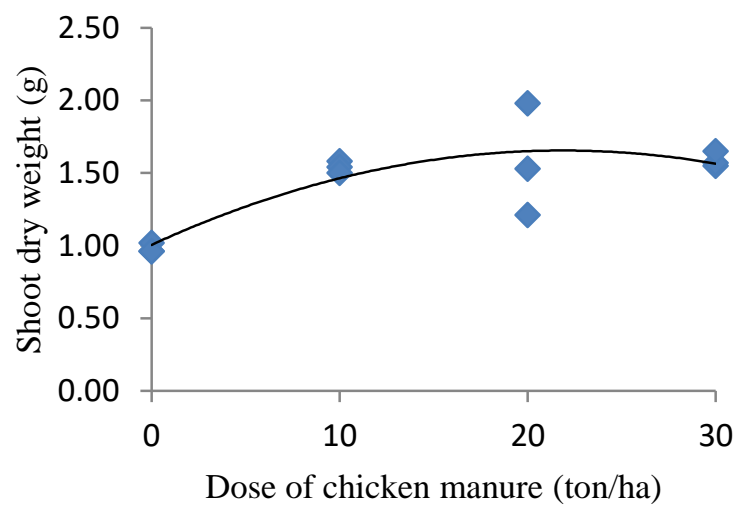

Figure 5. Effect of chicken manure on plant shoot dry weight

\section{CONCLUSIONS}

Application of dolomite $1 \mathrm{x}$ Al-ex and chicken manure 30 tons/ha improved tuber weight to $7.04 \mathrm{~g}$ and bulb diameter to $23.24 \mathrm{~mm}$. Chicken manure as single factor affected shallot plant on the variables of plant height, time to harvest, plant fresh weight, and plant dry weight. The optimal dose of chicken manure for shallot growth ranges 24 to 30 tons/ha. Dolomite as single factor increased plant height, time to harvest, plant fresh weight, plant dry weight. Dolomite lengthened time to harvest from 68,5 days to 71,5 days.

\section{REFERENCES}

[1] Central Bureau of Statistics, "Penduduk, Laju Pertumbuhan Penduduk, Distribusi Persentase Penduduk, Kepadatan Penduduk, dan Rasio Jenis Kelamin Penduduk Menurut Provinsi”, 2019. Access at

https://www.bps.go.id/indikator/indikator/view_data _ pub/ 0000/ api_pub/50/da_03/1.

[2] General Secretary of Agriculture. 2019. (http://epublikasi.setjen.pertanian.go.id/epublikasi/bu letin/
konsumsi/2019/Buletin\%20Konsumsi\%20Vol\%2010 $\% 20$ No\%201\%202019.htm).

[3] Ermadani, "Improvement of the chemical properties of ultisol soil and growth of Calopogonium with liming and N, P and K". Research Journal of Jambi University Science Series. 12 (2): 7-12. 2010.

[4] Yenni, Y., 2012. Ameliorasi tanah sulfat masam potensial untuk budidaya tanaman bawang merah (Allium ascalonicum L.). Jurnal Lahan Suboptimal 1(1) :28-43.

[5] Wahjudin.2006.Pengaruh pemberian kapur dan kompos sisa tanaman terhadap aluminium dapat ditukar danproduksi tanaman kedelai pada tanah vertic hapludult dari gajrug, Banten Agron34(3) :141 - 147.

[6] Manurung, M. 2016. Pengaruh dosis pupuk kandang terhadap pertumbuhan dan hasil kacang tanah (Arachys hipogea L.). Jurnal Ilmiah Research Sains 2(3) : 84-92

[7] Nugroho, W.A. and M.A. Firmansyah. 2016. Pengaruh jenis dan dosis pupuk kandang terhadap pertumbuhan dan produksi bawang merah di lahan kering dataran rendah. In Seminar Nasional Inovasi Teknologi Pertanian Banjarbaru : 906-912.

[8] Afrilliana, N., A. Darmawati, A. dan S. Sumarsono, 2017. Pertumbuhan dan hasil panen bawang merah (Allium ascalonicum L.) akibat penambahan pupuk $\mathrm{KCl}$ berbasis pupuk organik berbeda. Journal of Agro Complex 1(3) : 126-133.

[9] Nasution, R.M.F., L. Mawarni, and H. Haryati. 2017. Pengaruh populasi dan pemberian pukan ayam terhadap pertumbuhan dan produksi bawang merah (Allium ascalonicum l.). Jurnal Agroekoteknologi4 (4): 2293-2298.

[10] Syaputra, D., Alibasyah, M.R. and Arabia, T., 2015. Pengaruh kompos dan dolomit terhadap beberapa sifat kimia ultisol dan hasil kedelai (Glycine max L. Merril) pada lahan berteras. Jurnal Manajemen Sumberdaya Lahan, 4(1) :535-542.

[11] Trakal, L., Neuberg, M., Tlusos, P., Szakova, J., Tejnecky, V., and Drabek, O. 2011. Dolomite limestone application as achemical immobilization of metal-contaminated soil. Plant Soil Env. 57(4):173 179

[12] Salisbury, F.B and C.W.Ross. 1992. Plant Physiology. Wadsworth Publ. Co. USA

[13] Amara, D.J. and S. M. Mourad, 2013. "Influence of organic manure on the vegetative growth and tuber production of potato (Solanum tuberosum L. var Spunta) in a Sahara desert region", Intl .J.Agric. and CropSci., vol. 5(22),pp. 2724 - 2731.

[14] Damrongrak, J. Onthong, and C. Nilnond, " Effect of fertilizer and dolomite applications on growth and yield of tapping rubber trees", Songklanakarin J.Sci. Technol., vol. 37(6), pp. 643 - 650, Nov - Dec, 2015.

[15] Erhunmwunse, A. S., Olayinka, A., and Atoloye, I.A. 2019. Nutrient mineralization from Nitrogen - and Phosphorus- enriched poultry manure compost in an Ultisol. J. Com. In Soil Sci. And Plant Anal. 50 (2): $185-1$ 